\title{
Moisturizing effect of a cosmetic formulation containing pequi oil (Caryocar brasiliense) from the Brazilian cerrado biome
}

\author{
Wanessa Costa Silva Faria ${ }^{1}$, Gabriel Azevedo de Brito Damasceno², Márcio Ferrari* \\ ${ }^{1}$ University of Cuiabá, Cuiabá, MT, Brazil, ${ }^{2}$ Federal University of Rio Grande do Norte, Natal, RN, Brazil
}

\begin{abstract}
Caryocar brasiliense, popularly known in Brazil as "pequi", is a species widely distributed in the Brazilian Cerrado. The seeds are surrounded by a woody endocarp coated with a yellow fleshy mesocarp rich in oil and vitamin A, whose oil has a useful role in the treatment of skin aging and protection of human skin against UV-induced damage and skin hydration. The aim of this study was to evaluate the effect of cosmetic formulations containing pequi oil (Caryocar brasiliense) on skin hydration, after a single application. Hydration effect assessment was performed by applying the formulations under study (Control - no formulation, vehicle, and vehicle + pequi oil) onto forearm skin of 30 human volunteers. Skin capacitance and Transepidermal Water Loss (TEWL) measurements were analyzed before, and at 1,2 and 3 hours after, a single application. Evaluation results of a single application of the vehicle containing pequi oil showed an increase in stratum corneum water content, indicating a skin moisturizing effect. Results of the evaluation of immediate effects of TEWL demonstrated that the vehicle containing pequi oil significantly increased skin moisture during the $3 \mathrm{~h}$ evaluation period. The formulations containing pequi oil showed clinical efficacy, increasing stratum corneum water content and enhancing skin barrier function.
\end{abstract}

Uniterms: Caryocar brasiliense/pharmacognosy. Caryocar brasiliense/cosmetic use. Pequi oil/cosmetic formulations/effect. Skin hydration/use of pequi oil.

Caryocar brasiliense, popularmente conhecido como "Pequi", é uma espécie amplamente distribuída no Cerrado Brasileiro. O fruto é composto por sementes com endocarpo rígido e lenhoso, recoberto pelo mesocarpo carnoso, amarelado, rico em óleos e vitamina A, útil na proteção da pele contra raios UV, no tratamento das marcas senis da pele, bem como na hidratação cutânea. O objetivo deste estudo foi avaliar o efeito cosmético de formulações contendo óleo de pequi (Caryocar brasiliense) na hidratação cutânea, após uma única aplicação. Este efeito foi avaliado instrumentalmente através de medidas da capacitância da pele e pela perda de água transepidérmica após 1, 2 e 3 horas de uma única aplicação das formulações em estudo (controle, veículo e veículo + óleo de pequi) na pele do antebraço de 30 voluntários. Por meio das avaliações, a formulação contendo óleo de pequi aumentou o conteúdo de água no estrato córneo após 1, 2 e 3 horas, além de diminuir a perda de água transepidérmica, aumentando, significativamente, a hidratação cutânea durante as 3 horas de avaliação. A formulação contendo óleo de pequi apresentou eficácia clínica, aumentando o conteúdo aquoso do estrato córneo, bem como promovendo o efeito barreira na pele.

Unitermos: Caryocar brasiliense/farmacognosia. Caryocar brasiliense/uso cosmético. Óleo de pequi/ formulações cosméticas/efeito. Hidratação cutânea/uso do óleo de pequi.

\section{INTRODUCTION}

The skin has numerous functions and the stratum corneum (SC) is the most important skin barrier against exogenous physical and chemical influences while

*Correspondence: M. Ferrari. Departamento de Farmácia, Universidade Federal do Rio Grande do Norte. Rua Gustavo Cordeiro de Farias, s/n - Petrópolis, 59012-570 - Natal - RN, Brazil. E-mail: ferrarimarcio@uol.com.br also protecting against dehydration. Skin hydration is a complex and multifactorial process. Dry skin, also known as xerosis, can be caused and exacerbated by exogenous factors such as weather and lifestyle or by endogenous factors including medications, hormonal changes and aging (Pons-Guiraud, 2007). Skin hydration is related to suppleness, softness, smoothness as well as a youthful and healthy appearance (Jiang et al., 2011). The application of moisturizers can increase skin hydration and modify the 
physical and chemical nature of skin surfaces (Bonté et al., 2011; Walters et al., 2002).

Cosmetic products must undergo testing for efficacy and safety where bioengineering methods have been used to assess these under different conditions. The applications of noninvasive biometrical methods are growing rapidly, including for the determination of the effectiveness of natural ingredients for improving skin hydration such as Aloe vera (Piérard, 2002; Dal'Belo, 2006).

The measurement of transepidermal water loss (TEWL) is an indicator of the skin's barrier function. TEWL is a method for assessing the integrity of the skin barrier (Lodén, 2004). However, the measurement of capacitance indicates an increase or decrease of water content in the stratum corneum. This electrical property of the skin provides information to calculate hydration levels (Sotoodian et al., 2012).

The Brazilian Cerrado is the second largest biome in South America, recognized as the richest savanna in the world, being home to 11,627 native plant species catalogued to date. Over 220 species have medicinal uses and more than 10 kinds of edible fruit are regularly consumed by local people and sold in urban centers, such as Pequi (Caryocar brasiliense), Buriti (Mauritia flexuosa), Mangaba (Hancornia speciosa), Cagaita (Eugenia dysenterica) Bacupari (Salacia crassifolia), Cajuzinho cerrado (Anacardium humile), Araticum (Annona crassifolia) and Baru seeds (Dipteryxalata) (MMA, 2013).

Caryocar brasiliense, popularly known in Brazil as "pequi", is a tree species widely distributed in the Brazilian Cerrado (savannah-like vegetation) (Collevatti et al., 2003). Pequi are used for both human consumption and therapeutic purposes due to their antifungal, antiinflammatory and antioxidant activities (Araujo, 1995; Passos et al., 2002.; Paula-Junior et al., 2006; Oliveira et al., 2012), but their properties for use in cosmetic products remain largely unknown.

The seeds are surrounded by a woody endocarp coated with a yellow fleshy mesocarp rich in oil and vitamin A. The composition of pequi oil includes the presence of different fatty acids (palmitic, oleic, myristic, palmitoleic, stearic, linoleic and linolenic) (Facioli et al., 1998; Ferreira et al., 2011) as well as carotenoids (Azevedo-Maleiro et al., 2004). A special interest in vitamin A has emerged in recent years due to their useful role in the treatment of skin aging and the protection of human skin against UV-induced damage (Murray et al., 2008). Physical and chemical stability of cosmetic formulations containing vitamin $\mathrm{A}$ has been studied to ensure safety (Ibrahim, 2012). The fatty acids contained in oil are very similar to those present in the epidermis, allows to follow more than a cosmetic trend is the use of biomimetic products, encouraging skin-formulation compatibility. Considerable interest has been generated by its antioxidant capacity and several studies with vegetal species have been published recently (Gianeti et al., 2012; Zia-Ul-Haq et al.,2012).

In this context the aim of the present study was to evaluate the effect of cosmetic formulations containing pequi oil on skin hydration, after a single application, by using noninvasive bioengineering techniques, as well as to assess their effects on skin hydration properties: skin barrier function as measured by transepidermal water loss and stratum corneum hydration determined by capacitance measurements.

\section{MATERIAL AND METHODS}

\section{Formulations studied}

The stable $\mathrm{O} / \mathrm{W}$ emulsions studied were standardized by Pianoviski et al. (2008) and contained Acrylates/ C10-30 alkyl acrylate crosspolymer and carbomer (BFGoodrich, Dinaco SA, São Paulo, Brazil), caprylic/ capric triglyceride and oleyl alcohol (Croda do Brasil Ltda, Campinas, Brazil), BHT, dissodium EDTA, triethanolamine (Henrifarma Ltda, São Paulo, Brazil), methyldibromo glutaronitrile (and) phenoxyethanol (Tec pharmaLtda, São Paulo, Brazil) and Aqua. The formulations were supplemented or not (vehicle) with $10 \%$ (wt/wt) Caryocar brasiliense fruit oil (Croda do Brasil Ltda, Campinas, Brazil).

\section{Evaluation of in vivo efficacy}

This study was approved by the Research Ethics Committee of the University of Cuiabá (029/CEP/ UNIC/2007). A total of 30 volunteers with no history of previous skin disease were included in this study after having given their written informed consent. This study was designed as a one-sided blind, placebo-controlled study. The volunteers were instructed not to apply any topical products to the test sites during the 2 weeks before the study. Three sites on volunteers' forearm skin were chosen: one serving as the control where only measurements were taken, a second site to which $2.0 \mathrm{mg} / \mathrm{cm}^{2}$ of the formulation containing $10 \%$ Pequi oil (Vehicle + pequi oil) was applied, and a third site to which the formulation without oil (vehicle) was applied. The effects were studied on the volar side of both forearms.

Prior to all measurements, volunteers were left in 
the room for at least $30 \mathrm{~min}$ in order to allow full skin adaptation to the room's temperature $\left(20 \pm 2{ }^{\circ} \mathrm{C}\right)$ and humidity $(50 \pm 5 \%)$.

Stratum corneum moisture content was determined by noninvasive biometrical measurements using a skin capacitance meter (Courage \& Khazaka, Electronic GmbH, Khöln, Germany) (Fluhr et al., 1999a, 1999b) whereas transepidermal water loss was determined by an evaporimeter (Courage \& Khazaka, Electronic GmbH, Khöln, Germany) (Gioia et al., 2002). TEWL values were registered for 2 min following a 30 s period of equilibration of the probe on the skin. The baseline measurements (control areas-region which received no formulation) of skin hydration were taken after at least 30 min of acclimatization under standard climatic conditions. Skin capacitance and TEWL were determined before, and at 1 , 2 and $3 \mathrm{~h}$ after, application of the vehicle and formulation containing pequi oil. Three measurements were taken in each area on both the left and right forearms of volunteers at all time intervals for each treatment. The averaged values of 180 measurements were used for calculations.

\section{Statistical analyses}

Statistical analyses were performed using the software SPSS 13.0 for Windows (SPSS Inc., USA). Univariate analysis of variance and the post hoc test was carried out by using Tukey's multiple comparison test $(p<0.05$ was considered to be statistically significant).

\section{RESULTS AND DISCUSSION}

The active compounds used in cosmetic skin hydration can be divided into two major groups: hydrophilic and lipophilic agents, that act via four main mechanisms: by occlusion, humectant, hydration active rearrangement of stratum corneum and by inducing the formation of aquoporins (Bonté, 2011; Ribeiro et al., 2010; Caussin et al., 2009). According to Lodén (2004), the lipids in the moisturizers can increase skin hydration by several mechanisms. The most conventional is occlusion, which involves a reduction in TEWL.

There is growing interest in vegetal raw materials for use in cosmetic products. Unfortunately, the efficacy of many of these products has not been properly tested. This is the only study to date in which the formulation containing pequi oil has been evaluated by skin capacitance and TEWL.

The results obtained in the assessment of water content of stratum corneum with the formulation containing pequi oil revealed extremely significant differences $(\mathrm{p}<0.001)$ to control and vehicle-treated areas (Figure 1). More specifically, the results showed an increase in stratum corneum water content, indicating greater skin moisture, after 1, 2 and $3 \mathrm{~h}$ of evaluation following a single application. This formulation exhibited pronounced hydration effect on human skin. Changes in the amount of water in skin cause alterations in the local dielectric constant and consequently the capacitance (Wiedersberg et al., 2009). The Corneometer ${ }^{\circledR}$ is one of most widely used instruments to measure skin hydration by evaluating the capacitance of the skin's superficial layers and hence the state of hydration (Byrne, 2010; Darlenski et al., 2009). Thus, the results suggest that the hydration effect observed could be due an occlusion effect of the pequi oil present in the composition of the formulation under study. No significant differences were found between control and vehicle areas at $3 \mathrm{~h}$, and likewise among the three measurements (1, 2 and $3 \mathrm{~h}$ ) after a single application of the vehicle + pequi oil.

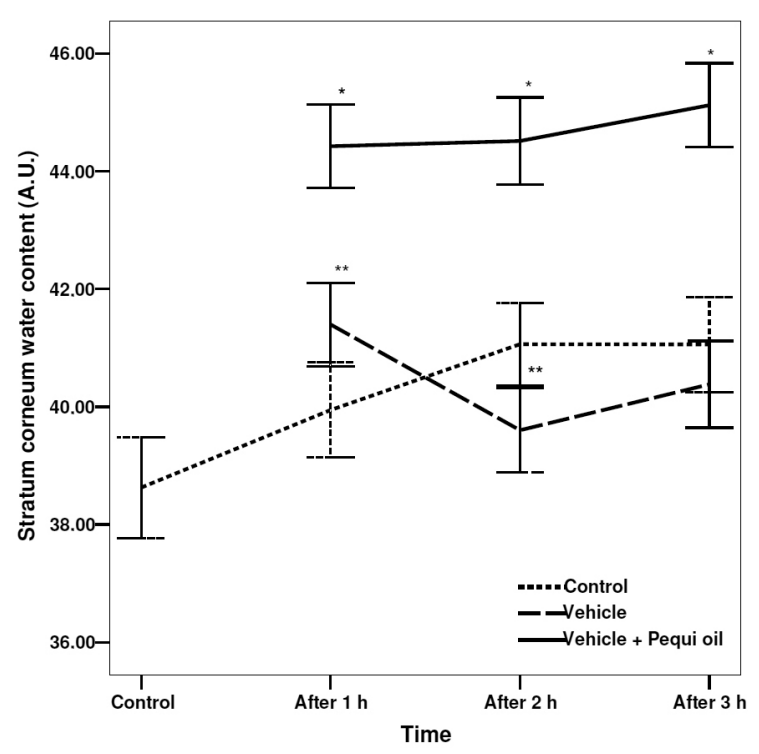

FIGURE 1 - Moisture content of stratum corneum before (control - baseline values) and at 1, 2 and 3 hours after, application of the formulation under study (Control - no formulation, Vehicle, Vehicle $+10 \%$ Pequi oil). Data are expressed as means and error bars represent confidence intervals $(95 \%) .{ }^{*} \mathrm{p}<0.05$ vs control and vehicle. ${ }^{* *}$ p $<0.05$ vs control and vehicle + pequi oil.

The evaluation of immediate effects of transepidermal water loss revealed that the vehicle containing pequi oil significantly increased skin moisture during the $3 \mathrm{~h}$ evaluation period after a single application compared with control and vehicle (Figure 2). The evaluation of TEWL is another important non-invasive technique for analyzing the efficiency of the skin's barrier function. This property 
of the stratum corneum is related to the organization of corneocytes and to skin condition.

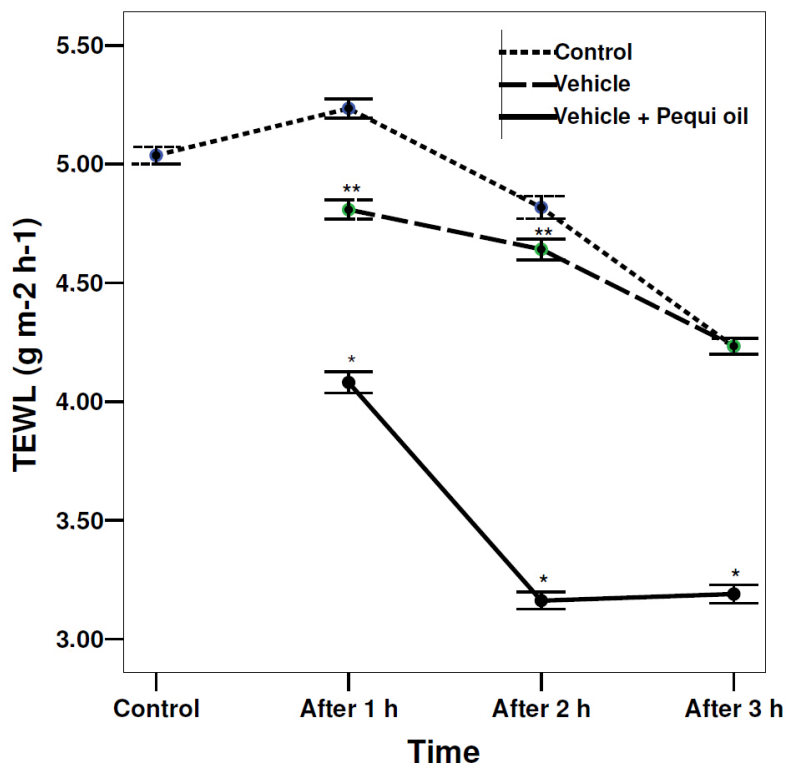

FIGURE 2 - Transepidermal water loss (TEWL) before (control - baseline values) and at 1,2 and 3 hours after, application of the formulation under study (Control - no formulation, Vehicle, Vehicle $+10 \%$ Pequi oil). Data are expressed as means and error bars represent confidence intervals $(95 \%)$. ${ }^{*} \mathrm{p}<0.05$ vs control and vehicle. $* * \mathrm{p}<0.05$ vs control and vehicle + pequi oil.

The Tewameter ${ }^{\circledR}$ is a device that determines the amount of transepidermal water loss based on the potential difference generated by the passage of water vapor via probe sensors. The results are given directly in grams of water loss per meter square per hour $\left(\mathrm{g} \mathrm{m}^{-2} \mathrm{~h}^{-1}\right)$. Under normal circumstances, values are usually below $8 \mathrm{~g} \mathrm{~m}^{-2} \mathrm{~h}^{-1}$ (Darlenski et al., 2009; Dykes, 2002).

A decrease in TEWL promotes an increase in skin hydration and barrier creams hydrate the skin by decreasing TEWL (Draelos, 2012). Significant differences were observed when comparing the pequi group with the control and vehicle groups up to the $2 \mathrm{~h}$ time point (Figure 2). At $3 \mathrm{~h}$ after a single application, the control and vehicle groups no longer differed significantly to the pequi group (Figure 2).

Figure 2 illustrates an immediate effect experiment. Beside this, the study by Dykes (2002) showed that within $30 \mathrm{~min}$, a decrease in TEWL values was evident, undoubtedly an occlusive effect of the lipophilic components of the formulation as opposed to barrier repair.

Therefore, we can conclude that pequi oil improved skin hydration most likely due to its lipids, promoting occlusion and decreasing TEWL, thereby confirming the utility of pequi oil as a moisturizing agent in cosmetic formulations.

\section{CONCLUSIONS}

In the present study, the influence of pequi oil on SC hydration and skin barrier function was demonstrated. The results of TEWL and stratum corneum water content values were in accordance, showing that TEWL values decreased while SC hydration values increased, improving both skin moisture level and skin barrier function. This study showed that pequi oil is a natural effective ingredient for improving skin hydration. The formulations containing pequi oil showed clinical efficacy (immediate effect) for stratum corneum water content and skin barrier function. Formulations containing pequi oil may therefore claim that the product improves barrier function and moisturizes the skin in the short term. Pequi oil can thus be used for moisturizing in different dermatological and cosmetic products.

\section{ACKNOWLEDGMENTS}

The authors are grateful to all volunteers for their participation. We also thank Croda of Brazil Ltda for the gift of sample materials. This work was supported by UNIC and by grants from Fundação de Amparo a Pesquisa do Estado de Mato Grosso - FAPEMAT.

\section{REFERENCES}

ARAUJO, F.A. Review of Caryocarbrasiliense (Caryocaraceae) an economicallyvaluable species of the Central Brazilian Cerrados. Econ. Bot., v.49, n.1, p.40-48, 1995.

AZEVEDO-MELEIRO, C.H.; RODRIGUEZ-AMAYA, D.B. Confirmation of theidentity of the carotenoids of tropical fruits by HPLC-DAD and HPLC-MS. J. Food Compos. Anal.,v.17, n.3-4, p.385-396, 2004.

BONTÉ, F. Skin moisturization mechanisms: new data. Ann. Pharm. Fr., v.69, n.3, p.135-141, 2011.

BYRNE, A.J. Bioengineering and subjective approaches to the clinical evaluation of dry skin. Int. J. Cosmet. Sci., v.32, n.6, p.410-421, 2010.

CAUSSIN, J.; ROZEMA, E.; GOORIS, G.S.; WIECHERS, J.W.; PAVEL, S.; BOUWSTRA, J.A. Hydrophilic and lipophilic moisturizers have similar penetration profiles butdifferent effects on $\mathrm{SC}$ water distribution in vivo. Exp. Dermatol., v.18, n.11, p.954-961, 2009. 
COLlevatti, R.G.; GRATtAPAGLiA, D.; HAY, J.D. Evidences for multiple maternallineages of Caryocarbrasiliense populations in the Brazilian Cerrado based on theanalysis of chloroplast DNA sequences and microsatellite haplotype variation. Mol. Ecol.,v.12, n.1, p.105-115, 2003.

DAL'BELO, S.E.; GASPAR, L.R.; MAIA CAMPOS, P.M.B.G. Moisturizing effect of cosmetic formulations containing Aloe vera extract in differentconcentrations assessed by skin bioengineering techniques. Skin Res. Technol., v. 12, n.4, p.241-246, 2006.

DARLENSKI, R.; SASSNING, S.; TSANKOV, N.; FLUHR, J.W. Non-invasive in vivomethods for investigation of the skin barrier physical properties. Eur. J. Pharm. Biopharm., v.72, n.2, p.295-303, 2009.

DYKES, P.J. What are meters measuring? Int. J. Cosmetic. Sci., v.24, n.4, p.241-245, 2002.

FACIOLI, N.; GONÇALVES, L. Modificação por via enzimática da composiçãotriglicerídica do óleo de pequi (Caryocar brasiliense Camb). Quím. Nova,v.21, n.1, p.16-19, 1998.

FERREIRA, B.S.; ALMEIDA, C.G.; FAZA, L.P.; DE ALMEIDA, A.; DINIZ, C.G.; SILVA, V.L.; GRAZUL, R.M.; HYARIC, M.L. Comparative Properties of Amazonian Oils Obtained by Different Extraction Methods. Molecules, v.16, n.7, p.5875-5885, 2011.

FLUHR, J.W.; GLOOR, M.; LAZZERINI, S.; KLEESZ, P.; GRIESHABER, R.; BERARDESCA, E. Comparative study of five instruments measuring stratum corneum hydration (Corneometer CM 820 and CM 825, Skicon 200, Nova DPM 9003, DermaLab). Part I. In vitro. Skin Res. Technol., v.5, n.3, p.161-170, 1999a.

FLUHR, J.W.; GLOOR, M.; LAZZERINI, S.; KLEESZ, P.; GRIESHABER, R.; BERARDESCA, E. Comparative study of five instruments measuring stratum corneum hydration (Corneometer CM 820 and CM 825, Skicon 200, Nova DPM 9003, DermaLab). Part II. In vivo. Skin Res.Technol., v.5, n.3, p.171-178, 1999b.

GIANETI, M.D.; GASPAR, L.R.; CAMARGO JR, F.B.; MAIA CAMPOS, P.M.B.G. Benefits of combinations of vitamin A, $\mathrm{C}$ and $\mathrm{E}$ derivatives in the stability of cosmetic formulations. Molecules, v.17, n.2, p.2219-2230, 2012.
GIOIA, F.; CELLENO, L. The dynamics of transepidermal water loss (TEWL) from hydrated skin. Skin Res. Technol.,v.8, n.3, p.178-186, 2002.

HARRIS, M.I.N.C. Pele: estrutura, propriedades e envelhecimento. 1.ed. São Paulo: Senac, 2003. 352 p.

HEINRICH, U.; KOOP, U.; LENEVEU-DUCHEMIN, M.C.; OSTERRIEDER, K.; BIELFELDT, S.; CHKARNAT, C.; DEGWERT, J.; HÄNTSCHEL, D.; JASPERS, S.; NISSEN, H.P.; ROHR, M.; SCHNEIDER, G.; TRONNIER, H. Multicentre comparison of skin hydration in terms of physical-,physiological- and product-dependent parameters by the capacitive method (Corneometer CM 825). Int. J. Cosmet. Sci., v.25, n.1-2, p.45-53, 2003.

IBRAHIM, T.A. Chemical composition and biological activity of extracts from Salvia bicolor Desf. Growing in Egypt. Molecules, v.17, n.10, p.11315-11334, 2012.

JIANG, Z.X.; DELACRUZ, J. Appearance benefits of skin moisturization. Skin Res. Technol.,v.17, n.1, p.51-55, 2011.

KIM, H.S.; LIM, S.H.; SONG, J.Y.; KIM, M.-Y.; LEE, J.H.; PARK, J.G.; KIM, H.O.; PARK, Y.M. Skinbarrier function recovery after diamond microdermabrasion. J. Dermatol., v.36, n.10, p.529-533, 2009.

LODÉN, M. Do moisturizers work? J. Cosmet. Dermatol., v.2, n.3-4, p.141-149, 2004.

MMA 2013. O bioma cerrado. Ministério do Meio Ambiente. Available at: $<$ http://www.mma.gov.br/>. Accessed on: 27 Apr. 2013.

MURRAY, J.C.; BURCH, J.A.; STREILEIN, R.D.; IANNACCHIONE, M.A.; HALL, R.P.; PINNELL, S.R. A topical antioxidant solution containing vitamins $\mathrm{C}$ and E stabilized byferulic acid provides protection for human skin against damage caused by ultraviolet irradiation. J. Am. Acad. Dermatol., v.59, n.3, p.418-425, 2008.

OLIVEIRA, L.M.D., RODRIGUES, A.G.; SILVA, E.F.D.; SILVA, E.F.; CERQUEIRA, L.B.; CASTRO, C.H.; PEDRINHO, G.R.; CARVALHO, M.H.C.; PONTAROLO, R.; COSTA, E.A.; CAMPOS, F.R.; FILGUEIRA, F.P.; GHEDINI, P.C. Endothelium-dependent vasorelaxant effect of butanolic fraction from Caryocar brasiliense Camb. leaves in rat thoracic aorta. J. Evid. Based Compl. Alt. Med.,v.2012, n.9, p.1-9, 2012. 
PASSOS, X.S.; SANTOS, S.C.; FERRI, P.H.; FERNANDES, O.F.L.; PAULA, T.F.; GARCIA, A.C.F.; SILVA, M.R.R. Antifungalactivityof Caryocar brasiliensis (Caryocaraceae) against Cryptococcus meoformans. Rev. Soc. Bras. Med. Trop., v.35, p.623-627, 2002.

PAULA-JUNIOR, W.; ROCHA, F.; DONATTI, L.; FADEL-PICHETH, C.; WEFFORT-SANTOS, A. Leishmanicidal, antibacterial, and antioxidant activities of Caryocarbrasiliense cambess leaves hydroethanolic extract. Rev. Bras. Farmacogn., v.16, suppl.1, p.625-630, 2006.

PIANOVSKI, A.; VILELA, A.; SILVA, A.; LIMA, G.; SILVA, K.; CARVALHO, V.F.M.; MUSIS, C.R.; MACHADO, S.R.P.; FERRARI, M. Desenvolvimento e avaliação da estabilidade de emulsões múltiplas $\mathrm{O} / \mathrm{A} / \mathrm{O}$ com óleo depequi (Caryocar brasiliense). Rev. Bras. Farm., v.89, n.2, p.155159, 2008.

PIÉRARD, G.E. Instrumental non-invasive assessments of cosmetic efficacy. J. Cosmet. Dermatol., v.1, n.2, p.57-58, 2002 .
PONS-GUIRAUD, A. Dry skin in dermatology: a complex physiopathology. J. Eur. Acad. Dermatol. Venereol., v.21, suppl.2, p.1-4, 2007.

SOTOODIAN, B.; MAIBACH, H.I. Noninvasive test methods for epidermal barrierfunction. Clin. Dermatol., v.30, n.3, p.301-310, 2012.

WALTERS, K.; ROBERTS, M. Dermatological and transdermal formulations. New York: Marcel Dekker, 2002. p.349-350.

WIEDERSBERG, S.; LEOPOLD, C.S.; GUY, R.H. Effects of various vehicles on skin hydration in vivo. Skin Pharmacol. Physiol., v.22, n.3, p.128-130, 2009.

ZIA-UL-HAQ, M.; AHMAD, S.; CALANI, L.; MAZZEO, T.; DEL RIO, D.; PELLEGRINI, N.; FEO, V. Compositional study and antioxidant potential of Ipomoea hederacea Jacq. and Lepidiumsativum L. seeds. Molecules. v.17, n.9, p.10306-10321, 2012.

Received for publication on $08^{\text {th }}$ May 2013 Accepted for publication on $22^{\text {th }}$ August 2013 